Med denne "fornuftens nødhjælp" bliver det tydeligt, hvorfor det oversanseliges genstand kun kan opfattes som tilgængelig ud fra en fejlslutning. Det forhold at vi i praktisk henseende selv konstruerer genstandene for den rene fornuft (idet de kan være behjælpelige for fornuftens ultimative mål) kan føre til, at man forveksler egne praktiske forestillinger med en objektiv realitet - $\mathrm{fx}$ forholdet mellem krop og ur. Situationen er nu, at fornuften kan opleves i strid med sig selv, idet det betingede anvendes på det ubetingede, og det er her hovedanken mod Leibniz og Wolff placeres.

Claus Asbjørn Andersen har oversat på forbilledlig vis og har fremfor alt turdet satse på en (mere) dansk sætningsopbygning. På trods af emnets specifikke karakter i forhold til det Kant'ske projekt fungerer Metafysikkens fremskridt som en glimrende indføring $i$, hvad det kritiske projekt fra Kants side går ud på: en afskærmning mod spekulativ metafysik som Kant så den udfolde sig hos Leibniz og Wolff. Ved at rette blikket mod hvorledes en kritisk metafysik nødvendigvis må se ud, kommer Kant uvægerligt til at behandle sin egen filosofi i et tilbageblik, der involverer forgængerne.

Frank Beck Lassen
Kunsten at gore de menneskelige ord guddommelige

Svend Bjerg: Det evige $i$ det fygtige. Kristendom i kortform. Gyldendal 2004, 200 s., 198 kr.

Svend Bjerg åbner sit Forord med ordene: "Bogen her har jeg skrevet på Skagen med daglig udsigt til et hav i evig bevægelse. Det er selve billedet på foreningen af det evige og det flygtige" (s. 7). Dette billede, hvor naturen skal bære det ultimative, vil jeg ikke yderligere omtale, selv om en af tidens trend igen er ved at blive naturoplevelser - og Bjerg benytter sig flittigt af dem i bogen. Derimod vil jeg tage afsæt i de næste indledende ord, der udkrystalliserer bogens titel samt tydeliggør bogens opbygning og xrinde: "Hvordan ser vore flygtige erfaringer ud, når de skildres under evighedens synsvinkel? Jeg vil vise, hvad der sker, når vi begynder at se på vore hverdagserfaringer - fødsel, kærlighed, skyld, bøn, arbejde, død - med kristelige øjne" (s. 7). Netop disse markante hverdagserfaringer er overskrifterne og tematikkerne i bogen, som vi får at vide kan læses hver for sig. Vi oplyses tillige om, at der her beskrives erfaringer, som alle kender, med den vigtige tilføjelse: "Hvad siger kristendommen om dem?".

Men hvad er kristendom egentlig? Det forsøger Bjerg også at svare på, for det har præcis at gøre med "det evige i det flygtige", og det har han sluttelig tilføjet to kapitler om ("evig 
flygtighed" og "flygtig evighed"), som jeg derfor på god paradoksal vis vil begynde med.

Præmissen er, at Guds eksistens ikke skal bevises, hvad der vil være tåbeligt, for så må man nødvendigvis forudsætte den Gud, der skal bevises, hvorefter tankerne kører i ring. Nej, Gud må erfares. Uden gudserfaring glemmes Gud, derfor drejer det sig om at finde frem til de elementære erfaringer, hvor livet åbner sig for en gudstale. Selv om Bjerg her går ind $\mathrm{i}$ en diskussion om, hvor Gud er, hvor både Tillich og Løgstrup dukker op (s. 165), vender han tilbage til den narrative teologi, som han blev kendt for allerede i 1981 med sin doktorafhandling Den kristne grundfortalling, der gjorde fortællingen til alfa og omega for kristendommen. Det er Guds ord, der skaber tro, og som sådan er Gud kreator, skaberen. De bibelske fortællinger er f.eks. ikke rekreation, men kreation, får vi at vide (s. 169). Og videre: "Vi har kun gudstro på sprogets betingelser" (s. 184). Det kan derfor ikke undre, at for Bjerg er alfabetet "livets hellige dna-kode" (s. 15). På den måde kan troen komme til mig, for den var der ikke på forhånd. At tro er at få den bibelske billedverden ind på nethinden, hvorefter man ser på verden med nye øjne og kan genbeskrive den. Dette udfolder og perspektiver Bjerg ved at skelne mellem oplevelse og erfaring, hvor oplevelse ikke må forstås i relation til det, vi i dag kalder oplevelsessamfundet: "Samfundet forbruger alt i oplevelsen, tag for dig og smid væk! Der levnes os aldrig den fornødne ro, så oplevelsen kan forvandles til en erfaring, der holder døren på klem til virkeligheden" (s. 173), siger han kritisk. Alligevel må afsættet være oplevelsen, men det skal være en oplevelse, der gør indtryk, og ikke en der bare skal forbruges og smides væk, oplevelsen skal bundfælde sig og hermed blive til en erfaring. Dét er det evige i det flygtige.

Det gennemgående er således en erfaringsproblematik, hvor der skelnes mellem to former for erfaring: Livserfaringen og troen der former livserfaringen (hvad der er et andet udtryk for den klassiske problemstilling: menneske og Gud), og det er præcis det hele Bjergs bog handler om, siger han selv (s. 174). Han har i bogen kapitel efter kapitel beskrevet erfaringen: "Jeg har genbeskrevet vore hverdagserfaringer kristeligt. $\mathrm{Og}$ ved genbeskrivelsen har det kristelige sprog fået mulighed for at erobre vort hverdagssprog. (...) Derved skulle det nye, kristelige liv gerne være gået op for læseren i skikkelse af berigede hverdagserfaringer" (s. 179). Idet hverdagen med dens erfaringer har evigheden i sig, er livet mellem fødsel og død også godt nok, og det er efter Bjergs mening det kristne budskab. Med denne viden kan vi nu se på, hvordan disse tanker mere konkret udfoldes i alle de foregående kapitler i bogen.

Tematikkerne er som næunt fødsel, kærlighed, skyld, bøn, arbejde og 
død, og for alle kapitler gælder, at de med eksempler beretter om forskellige fællesmenneskelige, hverdagslige oplevelser og fortællinger, der bliver sat ind i en kristen forståelsesramme og koblet med især psykologi og filosofi. Fødsel-kapitlet handler om det at blive født, skabt og genfødt og kulminerer med, at Jesu fødsel i tiden har "evig" betydning. Kapitlet om kærlighed handler lige så meget om Gud som om kærlighed, fordi Gud er kærlighed og hermed livsfylde, men også venskabet, erotikken og ægteskabet analyseres. Kapitlet om skyld fastholder ikke skylden som "en kristelig virus", men den konkretiseres $o g$ bindes til mennesker og fører til refleksioner om ret og retfærdighed, synd, tilgivelse og nåde. Med bønnen føres vi videre ind i kristendommen: "Bønnen er da et sted, der i ordene åbner sig for transcendens" (s. 106), men bønnen er også det at bede om noget, at vise den anden opmærksomhed, at hen-give sig til den anden. Først og fremmest er bønnen vigtig, fordi den fører Gud ind i verden og afgør, hvordan ens forhold er til Gud. Dette kapitel afsluttes med en analyse af fadervor. Herefter kommer arbejdet $\mathrm{i}$ fokus, der sammenlignes med legen og kontrasteres liv og glæde. Afslutningsvis følger temaet døden, hvor det på forskellig vis påvises, at kun det religiøse sprog kan hamle op med dødens realitet: Den der tror, går fra død til liv, til en evighed, der har lagt døden bag sig, og det kan ske, når tid slår om i rum, dvs. en ny form for tid, der fyldes af liv. Mere religiøst udtrykt: "Opstandelse (dødens død) og evigt liv (gudsnærvær) finder også sted i tiden her og nu" (s. 156).

Måske er egentlige afhandlinger om Gud uinteressante, for de bliver med Bjergs ord nemt til "teologiens dødbideri" (s. 184), derimod er essays a la disse den egentlige måde at forholde sig til Gud, fordi det er kristelige essays, der hele tiden er tæt på hverdagssproget. Selv om der undervejs er mistænkeligt mange henvisninger til Løgstrup (11 stk. og det vil sige den mest citerede tænker $i$ bogen), er det ikke først og fremmest en metafysisk anlagt Bjerg, vi møder her, men en fortælleglad kristen. Ud af intet skaber ordet liv, og der er ikke tvivl om, at Bjerg også forsøger at skabe liv, endda meningsfuldt liv, ikke ud af intet, men ud af en kontingent hverdag med Gud.

Ole Morsing

\section{Zygmunt Bauman}

Zygmunt Bauman: Frihed. Hans Reitzel, 2003, 148 s., 175 kr.; Zygmunt Bauman: Det belejrede samfund. Hans Reitzel, 2004, 368 s., 328 kr.; Zygmunt Bauman: Flydende karlighed. Hans Reitzel, 2004, 182 s., 225 kr.; Michael Hviid Jacobsen: Zygmunt Bauman - den postmoderne dialektik. Hans Reitzel, 2004, 412 s., $299 \mathrm{kr}$.

Hans Reitzels Forlag har gjort en kæmpe indsats for at udbrede kendskabet til Bauman. Det ville nærmest 